\title{
22. Democracy in Papua New Guinea: Challenges from a rights-based approach
}

\section{Orovu Sepoe}

PNG has encountered numerous challenges to its youthful and fledging democracy since independence in 1975. Against the background of critical issues facing the country, this chapter sets out to provide the rationale for and explore the importance of adopting a rights-based approach to strengthening democracy in PNG. The discussion also attempts to identify the opportunities offered by the rights-based approach for building a viable and meaningful democracy. Major legislative reforms and initiatives in institutional strengthening undertaken in PNG, in particular the Limited Preferential Voting system (LPV) and the Organic Law on the Integrity of Political Parties and Candidates (OLIPPAC), can serve as the means for strengthening democracy. A rights-based approach, applied through the LPV and the OLIPPAC, will establish a firm foundation for a bottom-up approach to building democracy. The rights-based approach needs to be considered as an alternative framework for strengthening and deepening democracy, and, more specifically, to ensure 'the people' become the focus of political practice in PNG.

The democratic system of governance, in its Western, liberal and representative form, is the model sought and promoted by the international community but its realisation has been problematic for many countries outside the West. In PNG, its introduction has been quite recent and the challenges emerging from this adoption process remain immensely difficult for a culturally heterogeneous society and historically autonomous clan- or tribal-based political entities.

In contemporary PNG political life, the peaceful and fair conduct of elections, an important hallmark of democratic government, remains an ideal. This paper suggests one pathway towards the realisation of this principle. It focuses specifically on two related aspects of electoral politics that have a tremendous bearing on democratic practice in PNG: the role of political parties as mechanisms of democracy and how voting behaviour, especially in the choice of political leadership, impacts on the quality of democracy.

There are two sections to this paper. The first section presents an overview and highlights some of the critical issues that continually threaten and weaken the functioning of a healthy democracy in PNG. The second section introduces the rights-based approach and the analytical framework that informs this discussion, and then proceeds to present the empirical reasons that necessitate a rights-based 
approach for strengthening democracy in PNG. The central argument in this discussion will be that a rights-based approach is critical for democracy. Applied through the OLIPPAC and the LPV system, it could help strengthen democracy in PNG. The critical question is how? In addressing this issue, the discussion will identify opportunities for strengthening democracy in PNG offered by the rights-based approach.

\section{The political context in PNG: Challenges and critical issues}

Symptoms of political decay are evident in PNG and these pose real risks for a healthy democracy (Gelu 2003). Endemic corruption, a general lack of government accountability to the people, the weak capacity of the State to deliver basic services, law and order, and a host of other governance issues endanger the effective functioning of institutions and the processes of democracy. The existence of a weak party system also poses formidable challenges for democracy. Party weakness results in political instability. There is also a lack of accountability where political party policies are displayed merely for voter enticement during elections rather than as a serious agenda for voters to base their decisions on, and much less for nation-building and promoting the common good. The weakness of PNG's party system results in threats of votes of no confidence in the Government, the frequency of which poses a major threat to political stability. Political instability turns the attention of government away from fulfilling its democratic mandate of serving the society and meeting its needs.

Election promises do not seem to bear fruit once political parties assume office. The result is poor delivery of services for a majority of the population. The political parties that form government in PNG have no concern for accountability to the people and no real basis for providing the linkage between government and society. Therefore, it is unreasonable for political parties in PNG to claim any affinity with the populace. The democratic role of political parties is often compromised as a result of their preoccupation with power games.

Poor political leadership is evident in widespread corruption, and mismanagement continues to impact negatively on democracy in PNG. Poor political leadership effectively means that the wellbeing and interests of people are not central to the thinking and conduct of elected leaders. People are deprived of basic security and suffer from many other forms of injustice. A dismal record of low indices of human development for PNG is illustrative of this point.

Weak state institutions are another established feature in PNG. Given the weak capacity of the State to deliver services for a majority of its citizens, the democratic link between citizens' aspirations and the activities of government agencies and elected representatives is effectively severed. This imposes serious constraints on the State's authority over society. 
Violence has become common in PNG elections, especially in the Highlands, seriously compromising the possibility of free and fair voting. Harassment, intimidation and bribery are common during elections and leave little room for a healthy electoral contest. Violence, actual or potential, has resulted in disenfranchisement for many citizens.

The acceptance and institutionalisation of democracy at the formal legal level has yet to be matched with the internalisation of human rights and the principles, norms and values of democracy in the national conscience. This is evident in the way Papua New Guineans today grapple with the notion of citizenship, which links individuals directly to the State but also poses difficulties for their traditional and familial relationships. This tension is evident in the electoral process in a number of ways: for instance, where voters prefer to choose wantok or haus lain candidates andthe prevalence of haus lain or bloc voting rather than one person, one vote.

Given the context of political life outlined above, it is imperative for PNG to embrace human rights in the electoral process. The next section attempts to analyse why and how rights are essential to the process of building and sustaining democracy in PNG.

\section{A rights-based approach to democracy}

At the outset, it is important to highlight that democracy is an issue of degree, not something that you either have or do not have. In addition, the values and principles intrinsic to democracy have to be acknowledged. These principles include 'popular control over public decision making and decision makers; and equality between citizens in the exercise of that control' (IDEA 2005). The democratic quality of a government is determined by taking these values seriously in political practice. These issues are explored through the context of electoral politics in PNG.

\section{Rights-based approach: A developmental perspective}

A rights-based approach deliberately and explicitly focuses on people achieving the minimum conditions for living with dignity. It does so by exposing the root causes of vulnerability and marginalisation and expanding the range of responses. It empowers people to claim and exercise their rights and fulfil their responsibilities. A rights-based approach recognizes poor, displaced, and war-affected people as having inherent rights essential to livelihood security, rights that are validated by international laws. (CARE 2001, in Uvin 2004)

The above definition of a rights-based approach to development has important lessons for political life and in particular democratic governance. Addressing the root causes of vulnerability is a central concern in a rights-based approach 
(Uvin 2004: 135). This requires identifying the systemic and structural causes of vulnerability preventing people from meaningful participation and exercising free choice in voting for people who will represent their interests. A rights-based democracy means, in effect, recognising democracy as people-centred and as a representative, participatory and developmental process.

\section{Analytical framework}

The human rights community recognises two broad categories of rights (Uvin 2004; Heywood 2004): civil and political rights and economic, social and cultural rights. In relation to civil and political rights, the important questions that must inform the discussion as well as the practice of democracy include:

- Are civil and political rights guaranteed equally for all?

- How effective and equal is the protection of the freedom of movement, expression, association and assembly?

- How secure is the freedom for all to practise their own religion, language or culture?

- How free from harassment are individuals and groups working to improve human rights? (IDEA 2005)

Economic, social and cultural rights encompass a range of special rights such as women's rights, children's rights and minority rights. This category accommodates the interests and needs of the vulnerable or marginalised, and they are given special consideration to overcome their relative disadvantage. The central purpose of a democratic system of government ought to be to serve the people and, in particular, how they can be empowered to participate in and benefit from processes of government.

\section{Empirical reasons for a rights-based approach}

Highlighted below are some observations that demonstrate the general disregard for rights in electoral politics and also provide a strong premise for a rights-based approach.

Does PNG enjoy free and fair elections? The highly competitive and volatile nature of elections in PNG is recognised widely by political commentators. Electoral contests are usually characterised by large numbers of competing candidates, averaging more than 20 candidates per electorate in 1997 and 2002 (May 2002; Okole and Kavanamur 2002). The 1992 national election signalled the beginning of violent elections in the Highlands. In his account of the Chimbu election in 1992, Bill Standish raised the first alarm relating to the harmful and destructive move 'towards gunpoint democracy'. By 2002, 'gunpoint democracy' was well and truly established in electoral politics in the Highlands. Another commentator's account of the 2002 election in Simbu reaffirms this point: 'Many people were not able to cast a vote. They were deprived of their rights as citizens 
by the use of guns, money and pigs throughout Chimbu and the rest of the Highlands region' (Dika 2003: 46). Lakane and Gibbs (2003: 109-13) also noted the widespread abuse of rights in the case of elections in Enga:

With so much at stake, voting becomes a matter of survival. Specific events of the 2002 election in Enga included hijacking of ballot boxes, the fire-bombing of ballot papers, shooting and killing ...

The experience of the 2002 elections shows a political culture developing in Enga which is neither just nor democratic. It is a culture of violence and intimidation, with links to traditional means of waging war and establishing alliances, but with new kinds of tribalism and a new type of leader who has access to guns and the ability to open or obstruct access to money and resources. The stakes are high with large discretionary 'electoral development funds' available to Members of Parliament and access by governors to Provincial Government funds. Elections are a form of investment, with successful candidates rewarding their supporters and disregarding others ...

Counting the cost of the last election, in money, soured relationships, and lives lost, people say that elections as experienced in 2002 are just not worth the trouble. For them, particularly the have-nots, it is not a question of money and miracles, but of poverty and a feeling of powerlessness.

Is political leadership determined through the exercise of democratic choice? To some extent, voters in PNG do exercise democratic choice in choosing their leaders. This is evidenced by the high turnover of MPs in all elections since 1977. In every election, two-thirds of sitting MPs have been voted out of office. However, in cases where guns, violence and intimidation are involved, as in most of the Highlands provinces, the choice of leadership is not democratic. Leadership choice is also gender-biased and discriminatory. The following testimony of a male voter's preference of leader is a stark revelation of gender discrimination: 'As much as I may want to vote for a woman candidate, the community and the tribe will despise or reject me, and even abandon me so I have to follow the way the community or tribe operates.' One observer gave the following account: 'During the 2002 national election in Enga, two women contested; one for the regional seat and the other for Wabag Open electorate. Most male candidates came out in public forums and said: "Women cannot climb a pandanus tree".' This metaphor means several things: women are not supposed to stand for election; women cannot win elections; and women cannot participate in politics and decision-making. 


\section{The Organic Law and LPV system: Opportunities for democracy in PNG}

The Organic Law on the Integrity of Political Parties and Candidates and the LPV system are the two most notable political reforms that PNG has undertaken to improve its governance since 2001. Current problems encountered in relation to the effective implementation of both have much to do with not taking rights seriously in PNG. Thus, it is crucial for rights to be considered as integral to the OLIPPAC and the LPV system. The overall lack of concern for principles, values and norms in the political life of the country ought to be a cause for concern. A similar point has been made by Louise Baker in her conceptualisation of 'integrity', where she argues that the OLIPPAC tends to emphasise the operational aspects of political party organisation and structure rather than the 'honesty' and 'uprightness' of the behaviour of key actors (Baker 2005: 213). Baker argues: 'The [OLIPPAC] has not been able to encourage all MPs to take initiatives to address public interests above and beyond their own, more limited interests' (2005: 114). A positive national consciousness and attitude reflecting respect for human rights can go a long way towards strengthening and sustaining democracy. While these are significant political reforms, their effectiveness is not fully realised because power dynamics take precedence over citizenship rights and respect for democratic norms and principles. Political parties need to play a leading role in strengthening democracy.

\section{The democratic role of political parties}

Several related issues must be considered as crucial to the democratic role of political parties: Are the rights of citizens promoted? Are people participating in political parties? How can rights become integral to the functioning of political parties? To what extent are political parties accountable for their election manifestos or policy platforms?

Fragmented, fluid and lacking any sort of discipline and popular membership, political parties tend to be more interested in power games than in fostering and promoting democratic governance. The obvious lack of commitment to party policies raises serious doubts about the democratic role of political parties. It raises questions about how political parties can be made accountable to popular demands and aspirations, and how they demonstrate their ability to address the diverse and varied interests and priorities of the people. In this respect, the OLIPPAC has to ensure that voters claim their right to hold political parties accountable for their stated policies. This requires the implementation agency of the OLIPPAC to be adequately resourced to carry out public awareness about reform and make it accessible for voters to obtain information on the policies of registered political parties. 
The elite-dominated and urban-based political parties' poor or non-existent linkage with society calls into question their democratic role. Encouraging grassroots membership is crucial for deepening democracy. The inclusion of a provision for a minimum of 500 members in the 1995 amendment to the OLIPPAC is a step in this direction, although much remains to be done in terms of ensuring that this provision is enforced well in advance of future elections. To be more gender inclusive, the OLIPPAC needs further amendment. Although Section 62 of the OLIPPAC provides financial incentives to political parties to endorse women candidates, this is insufficient. This needs to be complemented with the provision of a quota system for the endorsement of women by every registered political party.

\section{Limited Preferential Voting system}

Compared with the first-past-the-post system, the LPV system is arguably more democratic for PNG because it allows three choices for a voter. In an electorate with a large number of candidates, it also ensures that an MP is elected to office with more than 50 per cent of the votes from his/her electorate.

Under the first-past-the-post system in the 2002 national election, women in the Highlands generally did not vote. Their right to vote as individuals was blatantly abused and denied them. There was absolutely no freedom of choice, no freedom of expression and no freedom of movement in the Highlands. The election atmosphere was anarchic and the rule of law was non-existent in most parts of the Highlands during the election. Yet the MPs in power in the current Parliament and their supporters have not been held accountable for their illegal activities and inappropriate behaviour during the 2002 election, which clearly infringed the rights of voters, especially women. Even under the LPV system, women did not vote in the by-election held in the Anglimp South Wahgi open electorate. Instead, individuals appointed by contesting candidates marked the ballot paper for others, especially women. How can we ensure that women, indeed all voters, exercise their right to vote? A provision needs to be included in the LPV Act to effectively nullify the counting of votes for candidates who engage in bribery, intimidation and violence during an election. All candidates, and 'warlords' in particular, ought to be made accountable for their actions. In addition, separate polling booths for male and female voters should be provided to allow independent voting. In this way, the principles of secret and free voting, as well as more choice for voters, can be exercised effectively.

All the measures suggested above could help strengthen democracy in PNG.

\section{Conclusion}

Many Papua New Guineans are deprived of their basic rights during elections. Ironically, political leaders in PNG often go to great lengths to defend their own rights in the courts, especially for alleged involvement in corruption and 
misconduct. Yet they often infringe and abuse the rights of ordinary citizens in their quest to enter Parliament. Such political practice bears little resemblance to the democratic principles espoused in the PNG Constitution.

Although PNG is formally recognised as a Westminster parliamentary democracy, some of the underlying values and principles of this form of democracy have yet to take firm roots, especially in electoral politics. There are several critical issues, in particular a weak party system, group-voting behaviour and a harmful leadership culture, which require immediate attention if this country is to experience free and fair elections.

The central aim of this discussion was to offer an alternative approach to strengthening democracy. From a rights-based approach, some practical ways of achieving a people-centred, participatory and more representative democracy were suggested. Ultimately, a rights-based approach will require being sensitive to local power dynamics and political struggles. A rights-based democracy recognises the inevitably political nature of this approach. Through political struggle rights-based democracy is attainable (Uvin 2004).

There is a need for political parties to 'think human rights' in their operation. In this respect accountability is crucial. People's participation is crucial to realising the democratic role of political parties. The LPV system has to be premised on human rights claims to ensure the free and fair choice of competing candidates by voters. Ultimately, a rights-based approach would enable people to boldly claim their right to government services and political power.

\section{References}

Baker, Louise. 2005. 'Political integrity laws in Papua New Guinea and the search for stability.' Pacific Economic Bulletin, 20, 1 (May).

Democracy Assessment: The basics of the International IDEA Assessment Framework. 2005.

Dika, Elijah. 2003. 'The 2002 National Election in Chimbu Province.' Catalyst: Social Pastoral Journal for Melanesia, 33, 1.

Gelu, Alphonse. 2003. 'Political Decay in Papua New Guinea: The conduct of the 2002 National Election.' Catalyst: Social Pastoral Journal for Melanesia, 33, 1.

Gibbs, Philip. 2005. 'LPV and the Wabag Open By-Election.' Unpublished manuscript.

Grimshaw, Patricia, Katie Holmes and Marilyn Lake. 2001. Women's Rights and Human Rights: International historical perspectives. Basingstoke: Palgrave.

Heywood, Andrew. 2004. Political Theory: An Introduction. Third edition. New York: Palgrave Macmillan. 
Kanaparo, Peter. 2003. 'Democracy in Flames: Behaviours and Actions in the Heart of Wabag Town.' Catalyst: Social Pastoral Journal for Melanesia, 33,2 .

Kaupa, William Gari. 2003. 'PNG Culture and Politics: Election in the Gumine District 2002.' Catalyst: Social Pastoral Journal for Melanesia, 33, 1.

Lakane, J. and P. Gibbs. 2003. 'Haves and Have-Nots: The 2002 Elections in the Enga Province of PNG.' Catalyst: Social Pastoral Journal for Melanesia, 33,2 .

May, R. J. and R. Anere. 2002. Maintaining Democracy: The 1997 Elections in Papua New Guinea. Department of Political Science, UPNG.

Okole, Henry and David Kavanamur. 2002. 'Gender \& Governance in Papua New Guinea.' Unpublished manuscript.

Standish, Bill. 2003. 'Papua New Guinea's Most Turbulent Election.' Catalyst: Social Pastoral Journal for Melanesia, 33, 2.

Standish, Bill. 1996. 'Elections in Simbu: Towards Gunpoint Democracy?' In Yaw Saffu (ed.), The 1992 PNG Elections: Change and Continuity in Electoral Politics, Canberra: The Australian National University.

Uvin, Peter. 2004. Human Rights and Development. Bloomfield, CT: Kumarian Press. 